\title{
Association of serum hemoglobin A1c, C-peptide and insulin-like growth factor-1 levels with the occurrence and development of lung cancer
}

\author{
MEIYUN ZHANG, XIAOFENG LI, XINYI ZHANG, YONGYAN YANG, ZHIQING FENG and XIAOYAN LIU
}

Baotou Cancer Hospital, Baotou, Inner Mongolia 014030, P.R. China

Received September 19, 2013; Accepted April 8, 2014

DOI: $10.3892 / \mathrm{mco} .2014 .289$

\begin{abstract}
The present study aimed to investigate the correlation of the of hemoglobin A1c (HbA1c), C-peptide and insulin-like growth factor-1 (IGF-1) levels with the development and progression of lung cancer. The serum HbAlc, C-peptide and IGF-1 levels were measured and compared between 80 lung cancer patients and 80 healthy controls; furthermore, their correlation with histopathological type and tumor stage was analyzed in the 80 lung cancer patients. Our results suggested that the levels of HbA1c, C-peptide and IGF-1 were significantly increased in patients with lung cancer compared to those in the control group $(\mathrm{P}<0.05)$. In addition, the levels of C-peptide and IGF-1 were significantly higher in the small-cell lung cancer group $(n=18)$, the stage III-IV ( $n=55)$ group and the lung cancer with diabetes mellitus group $(n=43)$ compared to those in the non-small-cell lung cancer group $(n=62)$, the stage I-II lung cancer group $(n=25)$ and the lung cancer without diabetes group $(n=37)$, respectively $(\mathrm{P}<0.05)$. Thus, the present study suggests that the increased serum HbA1c, C-peptide and IGF-1 levels are significantly correlated with the development and progression of lung cancer.
\end{abstract}

\section{Introduction}

Malignant tumors and diabetes share common characteristics with regards to changes in the cellular and humoral immunity (1). The concentration of hemoglobin A1c (HbA1c) reflects the mean blood glucose levels over the last 8-12 weeks and it is known that long-term high blood sugar levels may cause cell immune-regulatory dysfunction and disturb T-lymphocyte proportions. The concentration of C-peptide, a concomitant of insulin, is increased due to ectopic hormone secretion from the tumor tissues, with a high level detected in the blood of

Correspondence to: Dr Meiyun Zhang, Baotou Cancer Hospital, 18 Tuanjie Street, Baotou, Qingshan, Inner Mongolia 014030, P.R. China

E-mail: zmy_130@sina.com

Key words: diabetes mellitus, lung cancer, hemoglobin A1c, C-peptide, insulin-like growth factor-1 patients with malignant tumors, including liver, colorectal and lung cancer $(2,3)$. Furthermore, the high expression levels of insulin-like growth factor-1 (IGF-1) in patients with diabetes mellitus may induce the overexpression of N-myc mRNA and protein and result in p53 dysfunction, abnormal cell senescence and cancer.

Among several risk factors associated with type II diabetes and lung cancer, lifestyle, diet and environmental factors bear significant similarities, suggesting that diabetes may increase the risk of lung carcinogenesis. In addition, the concentrations of $\mathrm{HbA} 1 \mathrm{c}, \mathrm{C}$-peptide and IGF-1 are closely associated with the development and progression of diabetes. An increasing number of studies reported that diabetes mellitus may affect the risk of developing a variety of cancers (4-7); however, the number of studies investigating the association between diabetes and lung cancer is limited. Therefore, the present study aimed to investigate the correlation between the levels of serum HbA1c, C-peptide and IGF-1 and lung carcinogenesis.

\section{Materials and methods}

Subjects. The study population included 80 lung cancer patients (49 men and 31 women, with a mean age of 62.1 years) treated at the Baotou Cancer Hospital (Inner Mongolia, China) between 2009 and 2011. The control group comprised 80 healthy subjects (51 men and 29 women, with a mean age of 60.6 years). Subjects with cardiovascular and cerebrovascular diseases, diabetes, high blood pressure, liver, kidney and endocrine diseases on physical examination were excluded from this study. The lung cancer patients were staged according to the 7th edition of the International Staging of Lung Cancer, 2009 (8). The diagnosis was confirmed by histopathological examination and the cases were classified as 62 with non-small-cell lung cancer (NSCLC) (24 with squamous cell carcinoma, 35 with adenocarcinoma, 1 with large-cell carcinoma and 2 with adenosquamous carcinoma) and 18 with small-cell lung cancer (SCLC). Among the 80 lung cancer patients, 25 had stage I-II and 55 had stage III-IV disease. No patients presented with primary lipid metabolism disorders. The diagnostic criteria for diabetes followed the current general international criteria provided by the World Health Organization Diabetes Expert Committee 1999 (9). This study was approved by the Institution Review Board (Baotou, China). 
Methods. Blood samples (2 ml) were collected from fasting subjects early in the morning. C-peptide levels were determined by immune chemiluminescence (10), HbAlc testing was conducted with high-pressure liquid chromatography analysis (11) and IGF-1 was measured using the double-antibody sandwich ELISA (12).

Statistical analysis. Statistical analysis was performed using SPSS statistical software, version 13.0 (SPSS, Inc., Chicago, IL, USA). The data are expressed as means \pm standard deviation. Significance was assessed using the two-sample Student's t-test for comparison of the corresponding serum indicators between the control and lung cancer groups, the NSCLC and SCLC groups, the stage I-II and stage III-IV lung cancer groups, as well as the lung cancer alone and the lung cancer with diabetes groups. All the statistical tests were two-sided and $\mathrm{P}<0.05$ was considered to indicate a statistically significant difference.

\section{Results}

Increased HbAlc, C-peptide and IGF-1 levels in the lung cancer group. The average fasting serum $\mathrm{HbAlc}$ was $6.11 \%$ in the control group $(n=80)$ and $7.00 \%$ in the lung cancer group $(n=80)$. Notably, the mean concentration of HbA1c in the lung cancer group was higher compared to the cut-off $\mathrm{HbAlc}$ level of $\geq 6.5 \%$ in the American Diabetes Association Clinical Practice Recommendations for the diagnosis of diabetes (13). The mean HbAlc level in the lung cancer group was significantly higher compared to that in the control group $(\mathrm{P}<0.05)$. Moreover, the levels of C-peptide $(4.97 \mathrm{ng} / \mathrm{ml})$ and IGF-1 $(297.34 \mu \mathrm{g} / \mathrm{ml})$ in the lung cancer group were significantly elevated compared to those in the control group $(3.25 \mathrm{ng} / \mathrm{ml}$ and $121.81 \mu \mathrm{g} / \mathrm{ml}$, respectively; $\mathrm{P}<0.01$ ) (Table I).

Differences in C-peptide and IGF-1 levels between the SCLC and NSCLC groups. As summarized in Table II, the mean levels of fasting serum C-peptide and IGF-1 were $2.75 \mathrm{ng} / \mathrm{ml}$ and $198.73 \mu \mathrm{g} / \mathrm{ml}$, respectively, in the NSCLC group $(\mathrm{n}=62)$. However, the levels of C-peptide and IGF-1 were $6.38 \mathrm{ng} / \mathrm{ml}$ and $338.97 \mu \mathrm{g} / \mathrm{ml}$, respectively, in the SCLC group $(\mathrm{n}=18)$. Moreover, the mean C-peptide and IGF-1 levels in the SCLC group were significantly higher compared to those in the NSCLC group $(\mathrm{P}<0.01)$, suggesting that $\mathrm{C}$-peptide and IGF-1 may be associated with different pathological types of lung cancer (Table II).

Increased HbAlc, C-peptide and IGF-1 levels in the advanced lung cancer group. The mean serum HbA1c was significantly increased in lung cancer patients with stage III-IV disease $(7.58 \%, n=55)$ compared to that in patients with stage I-II disease $(6.30 \%, \mathrm{P}<0.05)$ (Table II). In the advanced lung cancer group, the mean fasting serum C-peptide level was $4.50 \mathrm{ng} / \mathrm{ml}$, which was significantly higher compared to that in patients with stage I-II disease (3.03 ng/ml). Furthermore, the average IGF-1 level in the lung cancer group at stage III-IV was $303.41 \mu \mathrm{g} / \mathrm{ml}$, which was approximately two-fold higher compared to the mean IGF-1 level in lung cancer patients with stage I-II disease (162.93 $\mu \mathrm{g} / \mathrm{ml} ; \mathrm{P}<0.01)$ (Table III).
Table I. HbA1c, C-peptide and IGF-1 levels in patients with lung cancer.

\begin{tabular}{lccc}
\hline $\begin{array}{l}\text { Serum } \\
\text { indicators }\end{array}$ & $\begin{array}{c}\text { Control } \\
\text { group }(\mathrm{n}=80)\end{array}$ & $\begin{array}{c}\text { Lung cancer } \\
\text { group }(\mathrm{n}=80)\end{array}$ & P-value \\
\hline HbA1c, \% & $6.11 \pm 0.56$ & $7.00 \pm 0.82$ & $<0.05$ \\
C-peptide, $\mathrm{ng} / \mathrm{ml}$ & $3.25 \pm 0.76$ & $4.97 \pm 1.34$ & $<0.01$ \\
$\mathrm{IGF}-1, \mu \mathrm{g} / \mathrm{ml}$ & $121.81 \pm 41.54$ & $297.34 \pm 89.00$ & $<0.01$ \\
\hline
\end{tabular}

HbA1c, hemoglobin A1c; IGF-1, insulin-like growth factor-1.

Table II. Differences in C-peptide and IGF-1 levels between small-cell and non-small-cell lung cancer.

\begin{tabular}{lccc}
\hline $\begin{array}{l}\text { Serum } \\
\text { markers }\end{array}$ & $\begin{array}{c}\text { Non-small-cell } \\
\text { lung cancer } \\
(\mathrm{n}=62)\end{array}$ & $\begin{array}{c}\text { Small-cell } \\
\text { lung cancer } \\
(\mathrm{n}=18)\end{array}$ & P-value \\
\hline $\begin{array}{l}\text { C-peptide, } \mathrm{ng} / \mathrm{ml} \\
\text { IGF-1, } \mu \mathrm{g} / \mathrm{ml}\end{array}$ & $\begin{array}{c}2.75 \pm 1.87 \\
198.73 \pm 89.72\end{array}$ & $\begin{array}{c}6.38 \pm 1.54 \\
38.97 \pm 168.34\end{array}$ & $<0.01$ \\
\hline
\end{tabular}

IGF-1, insulin-like growth factor-1.

Table III. Increased HbA1c, C-peptide and IGF-1 levels in the advanced lung cancer group.

\begin{tabular}{lccc}
\hline $\begin{array}{l}\text { Serum } \\
\text { indicators }\end{array}$ & $\begin{array}{c}\text { Stage I-II } \\
(\mathrm{n}=25)\end{array}$ & $\begin{array}{c}\text { Stage III-IV } \\
(\mathrm{n}=55)\end{array}$ & P-value \\
\hline HbA1c, $\%$ & $6.30 \pm 0.46$ & $7.58 \pm 0.78$ & $<0.05$ \\
C-peptide, ng/ml & $3.03 \pm 1.75$ & $4.50 \pm 1.49$ & $<0.05$ \\
IGF-1, $\mu \mathrm{g} / \mathrm{ml}$ & $162.93 \pm 84.84$ & $303.41 \pm 112.45$ & $<0.01$ \\
\hline
\end{tabular}

HbA1c, hemoglobin A1c; IGF-1, insulin-like growth factor-1.

Table IV. Differences in C-peptide and IGF-1 levels between lung cancer patients with and those without diabetes mellitus.

\begin{tabular}{|c|c|c|c|}
\hline Indicators & $\begin{array}{l}\text { Lung } \\
\text { cancer } \\
(n=37)\end{array}$ & $\begin{array}{l}\text { Lung cancer } \\
\text { with diabetes } \\
\text { mellitus }(n=43)\end{array}$ & P-value \\
\hline C-peptide, ng/ml & $2.07 \pm 0.83$ & $4.66 \pm 1.69$ & $<0.05$ \\
\hline $\mathrm{IGF}-1, \mu \mathrm{g} / \mathrm{ml}$ & $182.28 \pm 91.76$ & $349.72 \pm 198.88$ & $<0.01$ \\
\hline
\end{tabular}

IGF-1, insulin-like growth factor-1.

Differences in C-peptide and IGF-1 levels between lung cancer patients with and those without diabetes. As shown in Table IV, the mean C-peptide level in lung cancer patients with diabetes mellitus $(\mathrm{n}=43)$ was $4.66 \mathrm{ng} / \mathrm{ml}$, which was significantly higher compared to that in patients with lung cancer without diabetes mellitus ( $\mathrm{n}=37 ; 2.07 \mathrm{ng} / \mathrm{ml})$. C-peptide is secreted in 
the same amount as insulin and, therefore, accurately reflects the amount of insulin secretion. Therefore, the increased levels of C-peptide may be associated with the development of lung cancer in patients with type II diabetes. In addition, the mean level of IGF-1 was significantly increased in lung cancer patients with diabetes mellitus $(349.72 \mu \mathrm{g} / \mathrm{ml})$ compared to that in patients with lung cancer alone $(182.28 \mu \mathrm{g} / \mathrm{ml} ; \mathrm{P}<0.01)$.

\section{Discussion}

It was previously demonstrated that, with increasing levels of HbA1c, the levels of tumor markers CEA, CA199 and CA153 in patients are gradually increased, suggesting that high blood sugar levels may promote cell expression of tumor markers (14). In this study, the HbAlc level was significantly increased in patients with lung cancer, particularly those with advanced-stage disease (stage III-IV), suggesting that HbA1c may be associated and potentially contribute to the development of lung cancer.

Cust et al (15) reported that, in patients with lung cancer and liver metastases, the levels of fasting serum C-peptide were significantly increased. However, a correlation between the changes of C-peptide levels and lung cancer histology was not established. This study demonstrated that C-peptide levels were significantly higher in lung cancer patients compared to those in the control group. As lung cancer progresses from early- to late-stage, the C-peptide levels also increase significantly; the levels of C-peptide were significantly higher in the SCLC compared to that in the NSCLC group, suggesting a significant correlation between fasting serum C-peptide levels and the occurrence and development of lung cancer.

Casa et al (16) demonstrated that the serum IGF-1 levels in patients with NSCLC were significantly decreased following effective chemotherapy and were significantly higher in the ineffective chemotherapy group. The subjects with high IGF-1 levels exhibited a significantly higher risk of cancer development. Blocking the IGF-1 signaling pathway by antisense oligonucleotides or RNA interference technology may significantly inhibit the growth and proliferation of tumor cells. Previous evidence $(17,18)$ demonstrated that the IGF-1 signaling pathway is involved in multiple mechanisms underlying tumorigenesis, mitosis, metastasis, angiogenesis and antiapoptosis, and is also involved in tumor resistance to chemotherapy, radiotherapy, human epidermal growth factor receptor 2 and epidermal growth factor receptor-targeted therapy. In the present study, when comparing the lung cancer with the control group, the SCLC with the NSCLC group, the late- with the early-stage lung cancer group and the lung cancer alone with the lung cancer plus diabetes groups, the IGF-1 levels were found to be significantly increased in the study groups. Our results suggested that IGF-1 may be closely associated with the occurrence and development of lung cancer, a finding that may help improve chemotherapy and radiation therapy for lung cancer.
In future studies, we plan to increase the sample size; furthermore, by measuring islet function in patients with lung cancer, monitoring blood glucose, tracking the type and dose of hypoglycemic drugs and perform follow-ups on the survival of lung cancer patients with and without diabetes, we aim to investigate the correlation between diabetes mellitus and the risk of lung cancer.

\section{References}

1. Zhang H, Wu XK, Li B, et al: The interaction between cancer and diabetes. Chin J Gerontol 30: 3187-3188, 2010.

2. Chen HB and Chen SA: Analysis of serum glucose, insulin and and C-peptide levels in 56 liver cancer patients. Int J Lab Med 28: 496-497, 2007.

3. Fu XJ: The relationship between C-peptide and glycosylated hemoglobin in type 2 diabetes and colorectal cancer. Pract Clin Med 10: 38-39, 2009.

4. Will JC, Vinicor F and Calle EE: Is diabetes mellitus associated with prostate cancer incidence and survival? Epidemiology 10: 313-318, 1999.

5. Adami HO, McLaughlin J, Ekbom A, et al: Cancer risk in patients with diabetes mellitus. Cancer Causes Control 2: 307-314, 1991.

6. Will JC, Galuska DA, Vinicor F, et al: Colorectal cancer: another complication of diabetes mellitus? Am J Epidemiol 147: 816-825, 1998.

7. Calle EE, Murphy TK, Rodriguez C, et al: Diabetes mellitus and pancreatic cancer mortality in a prospective cohort of United States adults. Cancer Causes Control 9: 403-410, 1998.

8. Edge S, Byrd DR, Compton CC, Fritz AG, Greene FL and Trotti A: AJCC Cancer Staging Manual (Eds) 7th edition. Springer, New York, 2010.

9. World Health Organization: Definition, diagnosis and classification of diabetes mellitus and its complications: Report of a WHO Consultation. Part 1. Diagnosis and classification of diabetes mellitus. Geneva, World Health Organization, 1999.

10. Han ST, Li XS and Chu Q: The establishment of measurement of C-peptide by chemiluminescence immunoassay. J Beihua Univ (Natural Science) 5: 58-60, 2004 (In Chinese).

11. Tu GH, Jiang XG, Li L, et al: Establishment and evaluation of HPLC method for glycated hemoglobin and measurement. J Jiangsu Univ (Medical Edition) 21: 147-150, 2011.

12. Liu XD and Guo XT: Explore the level of serum insulin-like growth factor-1 in patients with hypertension. J Clin Med 16: 264-265, 2007.

13. American Diabetes Association: Standards of Medical Care in Diabetes-2012. Diabetes Care 35 (Suppl 1): S11-S63, 2012.

14. Meiling: The tumor serum vascular endothelial growth factor and clinical significance of hemoglobin. J Clin Pract 12: 104-105, 2009.

15. Cust AE, Kaaks R, Friedenreich C, et al: Metabolic syndrome, plasma lipid, lipoprotein and glucose levels, and endometrial cancer risk in the European Prospective Investigation into Cancer and Nutrition (EPIC). Endocr Relat Cancer 14: 755-767, 2007.

16. Casa AJ, Dearth RK, Litzenburger BC, et al: The type I insulin-like growth factor receptor pathway: a key player in cancer therapeutic resistance. Front Biosci 13: 3273-3287, 2008.

17. Gunter MJ, Hoover DR, Yu H, et al: Insulin, insulin-like growth factor-I, and risk of breast cancer in postmenopausal women. J Natl Cancer Inst 101: 48-60, 2009.

18. Qian J, Dong A, Kong M, et al: Suppression of type 1 insulin-like growth factor receptor expression by small interfering RNA inhibits A549 human lung cancer cell invasion in vitro and metastasis in xenograft nude mice. Acta Biochim Biophys Sin (Shanghai) 39: 137-147, 2007. 